\title{
Kontribusi Tindak Pembelajaran Guru Kelas 1 SDN pada Peningkatan Keterampilan Menulis Siswa
}

\author{
Luh Desy Handayani1 ${ }^{*}$, M.G Rini Kristiantari², Ni Wayan Suniasih ${ }^{3}$ \\ 123 Program Studi Pendidikan Guru Sekolah Dasar, Universitas Pendidikan Ganesha, Singaraja, Indonesia
}

\begin{abstract}
Abstrak
Penelitian ini bertujuan untuk menganalisi kontribusi tindak pembelajaran guru kelas 1 SD Negeri 2 Dangin Puri pada peningkatan keterampilan menulis siswa tahun ajaran 2019/2020. Pendekatan dalam penelitian adalah deskriptif kualitatif dengan jenis penelitian entografis. Subjek terteliti adalah guru kelas 1 SD Negeri 2 Dangin Puri dan siswa kelas 1 berjumlah 27 orang. Data penelitian dikumpulkan dengan teknik observasi dan wawancara. Sebagai instrumen kunci dalam penelitian adalah peneliti sendiri hadir di lapangan dilengkapi dengan lembar observasi dan wawancara. Data yang terkumpul selanjutnya dianalisis secara deskriptif kualitatif dengan tahapan pengumpulan data, reduksi data, paparan data, penarikan simpulan. Temuan penelitian ini menunjukkan bahwa Kontribusi Tindak Pembelajaan Guru Kelas 1 SD Negeri 2 Dangin Puri Pada Peningkatan Keterampilan Menulis dalam kategori Structuring guru cenderung mengingatkan siswa teknik menulis yang baik. Kategori Soliciting, kecenderungan guru memberikan tugas kepada siswa berupa membuat kalimat. Kategori Reacting, guru cenderung membimbing dan penguatan berupa memotivasi, menegur disertai tindakan nonverbal berupa ekspresi wajah dan gerak tubuh seperti menunjuk dan tepuk tangan. Temuan terkait dengan alasanalasan melatarbelakangi guru dalam menampilkan tindak pembelajaran tertentu, pertama agar siswa lebih bersemangat dan berkonsentrasi dalam belajar terutama dalam keterampilan menulis, kedua agar peningkatan dalam pemahan tentang keterampilan menulis baik, ketiga guru berharap agar siswa menjadi disiplin.
\end{abstract}

\begin{abstract}
This research aims to analyze the contribution of classroom 1 teacher learning actions at SD Negeri 2 Dangin Puri in improving students' writing skills in academic year 2019/2020. The approach in this research is descriptive qualitative with type of ethnographic research. Subjects studied is teacher of grade 1 at SD Negeri 2 Dangin Puri and grade 1 students totaling 27 people. Research data were collected by observation and interview techniques. As a key instrument in this research is the researcher himself who is present in the field equipped with observation sheets and interviews. The collected data is then analyzed descriptively qualitatively with the stages of data collection, data reduction, data exposure, and drawing conclusions. The findings of this study indicate that the Contrubution of Teacher Learning Activities in Class 1 of SD Negeri 2 Dangin Puri on Improving Writing Skills in the Stucturing category teachers tend to remind the student of the correct writing technique. Soliciting category, the tendency of teachers to give assignments to students make a sentence. In the Reacting category, teachers tend to guide, motivate, reprimand and provide reinforcement accompanied by nonverbal actions in the form of smiles and such gesturing and applause. The findings are related to the reasons behind the teacher in presenting certain acts of learning, first so that students are more enthusiastic and concentrated in learning especially in writing skills, secondly, for better comprehension of writing skill, thirdly the teachers hopes that the students will be dicipline.

Keywords:

Teacher Learning Action, Writing Skill
\end{abstract}

\footnotetext{
${ }^{*}$ Corresponding author. 


\section{PENDAHULUAN}

Pendidikan merupakan faktor penting dalam meningkatkan kualitas sumber daya manusia yang dapat diberikan melalui bimbingan. Dengan demikian, diharapkan pendidik dapat melakukan bimbingan serta pengajaran pada peserta didik hingga pada akhirnya peserta didik menjadi pribadi yang dewasa, serta mampu dan siap untuk menghadapi perkembangan di era global.

Adapun seperangkat rencana yang dipakai sebagai acuan penyelenggaraan pendidikan adalah kurikulum. Kurikulum 2013 menekankan pada aspek kognitif, afektif dan psikomotorik secara proposional sesuai dengan karakteristik siswa. Pada pembelajaran kurikulum 2013 ini memiliki beberapa keunggulan yaitu: munculnya siswa yang berkarakter, siswa menjadi lebih aktif, kreatif dan inovatif. Pembelajaran kurikulum 2013 berlangsung secara temaik terpadu (tematik integratif). Pembelajaran tematik merupakan pendekatan pembelajaran dengan memadukan berbagai kompetensi dari berbagai mata pembelajaran ke dalam berbagai tema. Adapun mata pelajaran yang dimaksud antara lain IPA, IPS, Matematika, PPKn, SBdP, Penjaskes dan Bahasa Indonesia. Kurikulum yang mencangkup berbagai mata pelajaran menuntut siswa terampil dalam berbagai bidang, termasuk terampil dalam menulis.

Keterampilan menulis sangat berperan penting bagi siswa untuk mengembangkan kemampuan menggunakan pola-pola bahasa, penyampaian informasi dalam penyampaiannya secara tertulis. Menurut Dalman (2014) menulis adalah kegiatan berupa penyampaian pesan (informasi), pikiran, angan-angan, perasaan dalam bentuk tulisan. Tarigan (2005) mengemukakan bahwa menulis ialah melukiskan lambang-lambang grafis berupa suatu bahasa yang dapat dipahami oleh seseorang. Jadi, dapat dikatakan bahwa menulis merupakan wujud dari ide atau gagasan.

Semua siswa membutuhkan dasar keterampilan menulis yang mumpuni. Segala aktivitas manusia yang diungkapkan dengan berbagai cara itu mengandung suatu makna atau tujuan. Begitu juga bahasa yang dituangkan ke dalam bentuk lisan merupakan curahan ide, perasaan, pendapat yang dirangkai melalui kata-kata, untuk meningkatkan kemampuan peserta didik dalam berkomunikasi. Bahasa memegang peranan penting dalam kehidupan manusia karena bahasa merupakan alat komunikasi manusia dalam kehidupan sehari-hari. Dengan bahasa, seseorang dapat menyampaikan ide, pikiran, perasaan atau informasi kepada orang lain, baik secara lisan maupun tulisan. Manusia dalam mengungkapkan bahasanya pun berbeda-beda, ada yang lebih suka langsung membicarakannya dan ada juga yang lebih suka melalui tulisan.

Seperti halnya kemampuan berbicara, kemampuan menulis mengandalkan kemampuan berbahasa yang sifat aktif dan produktif. Pengembangan kemampuan atau keterampilan menulis melibatkan banyak jenis kompetensi dan keterampilan dalam menggunakan struktur-struktur linguistik kosakata, tatabahasa atau wacana. Menulis dapat dipandang sebagai proses generative, yaitu proses yang tidak didasarkan pada rencana tertentu. Kegiatan menulis banyak digunakan sebagai cara untuk mengekspresikan hal-hal yang bersifat personal bagi siswa sampai sekarang. Tugas menulis bisa bermacam-macam bentuknya, mulai dari mengisi formulir sampai menyajikan informasi ataupun penggunaan bahasa secara imajinatif.

Peningkatan kemampuan menulis memerlukan pemahaman tentang bagaimana cara menggabungkan komeponen-komponen linguistik (pengetahuan tentang kosakata, tatabahasa, ortografi, struktur genre) agar menghasilkan sebuah teks. Koreksi atau masukan salah satu dari sekian banyak aspek dalam pengajaran kemampuan keterampilan menulis. Penelitian-penelitian terhadap keterampilan menulis difokuskan pada masalah-masalah seperti koreksi kesalahan, strategi komposisi dan peran dari guru dalam proses penulisan.

Penanaman kemampuan menulis sebaiknya dilakukan sejak dini. Pada dasarnya, pertumbuhan dan perkembangan anak usia dini menentukan perkembangan anak selanjutnya. Kelas 1 merupakan jenjang pendidikan peralihan anak dari taman kanak-kanak menuju pembelajaran yang lebih formal. Siswa kelas 1 termasuk ke dalam perkembangan kognitif pada tahap Operasional Kontret. Pada tahap ini peserta didik sudah mampu berpikir rasional, seperti menalar untuk menyelesaikan suatu permasalahan. Banyak hal yang perlu diperhatikan dalam pembelajaran untuk meningkatkan keterampilan menulis pada tingkat awal sekolah dasar, sebab siswa belum memiliki bekal pengetahuan yang cukup, sehingga peran guru sangatlah penting. Sesuai dengan perannya, guru membantu peserta didik yang sedang berkembang untuk mempelajari sesuatu yang belum diketahuinya. Guru memiliki wewenang dan tanggung jawab terhadap anak didiknya.

Guru selain bertugas untuk mengajar yang secara umum didefinisikan menyampaikan materi pelajaran kepada siswa, guru juga dituntut untuk mampu mendidik siswa menjadi pribadi yang memiliki akhlak mulia, berbakti kepada orang tua serta guru maupun mengabdikan diri untuk masyarakat.Pada dasarnya misi utama pendidikan adalah pembentukan keterampilan hidup sebagaimana empat pilar pendidikan, bukan sekedar penguasaan materi pengetahuan. Maka dari itu perlu dipikirnkan langkah- 
langkah proses pendidikan yang memungkinkan terwujudnya sumber daya menusia yang berkualitas, salah satunya adalah guru, lebih khusus lagi adalah guru.

Menurut Hamza (2016) guru merupakan pengajar dan pendidik dalam pendidikan anak usia dini disekolah. Guru merupakan unsur yang paling penting dalam proses pendidikan. Tanpa adanya guru, pendidikan hanya menjadi slogan dan pencitraan karena segala bentuk kebijakan dalam sektor pendidikan pada akhirnya yang akan menentukan tercapainya tujuan pendidikan adalah guru. Guru menjadi titik sentral dan awal dari semua pembangunan pendidikan.Guru merupakan sosok yang digugu dan ditiru oleh siswa sesuai dengan peranannya sebagai orang tua kedua di sekolah, terutama bagi siswa kelas rendah. Oleh karena itu, peningkatan keterampilan menulis tidak hanya difokuskan pada kemampuan kognitif siswa saja, tetapi juga diperlukan tindakan-tindakan pembelajaran yang tepat oleh guru agar meciptakankan suasana dan pengalaman belajar yang bermakna bagi siswa.

Tindak pembelajaran guru yang menumbuhkembangkan kreativitas siswa SD kelas rendah penting dilakukan karena berpikir, sikap, dan tingkah laku kreatif berkembang dengan pesat mulai taman kanakkanak sampai kelas tiga, tetapi perkembangan kreativitas anak umur 5-6 tahun sampai masuk sekolah dihambat.

Rumusan masalah dalam penelitian ini adalah, tindak-tindak pembelajaran seperti apakah yang dilakukan oleh guru kelas 1 yang berkontribusi pada peningkatan keterampilan menulis siswa serta alasan-alasan apakah yang melatarbelakangi guru kelas 1 dalam penampilkan tindak pembelajaran tertentu pada saat pembelajaran yang berkontribusi pada peningkatan keterampilan menulis siswa.

Adapun tujuan penelitian ini adalah Untuk mengungkap bentuk tindak pembelajaran guru kelas 1 SD pada proses pembelajaran yang berkontribusi pada peningkatan keterampilan menulis siswa.Untuk mengungkap alasan-alasan yang melatarbelakangi guru kelas 1 SD dalam menentukan tindak pembelajaran pada saat mengajar yang berkontribusi pada peningkatan keterampilan menulis siswa. Penelitian yang dilakukan oleh Moh. Irtadji (2014) menunjukkan bahwa banyak tindak pembelajaran yang dilakukan oleh guru agar bisa menumbuhkembangkan kreativitas siswa adalah menciptakan lingkungan psikologis yang aman dan menggunakan berbagai macam metode pembelajaran. Tindak pembelajaran tersebut diantaranya yaitu Teacher Structuring, Teacher Soliciting, Teacher Reacting dan Student Responding. Penelitian oleh Yanti dkk (2013), menyatakan perbedaan signifikan keterampilan menulis karangan narasi dalam mata pelajaran Bahasa Indonesia antara kelompok siswa yang mengikuti pembelajaran model Moody dengan memanfaatkan cerita rakyat siswa dibelajarkan pembelajaran konvensional pada siswa kelas IV SDN 1 Ubud yang dibuktikan bahwa skor keterampilan menulis karangan narasi pada siswa yang mengikuti pembelajaran Moody dengan memanfaatkan cerita rakyat lebih tinggi dari siswa yang mengikuti pembelajaran konvensional.

Berdasarkan permasalah masih adapun beberapa faktor yag menjadi kendala pada penerapaan keterampilan menulis pada siswa antara lain: ada siswa yang tidak bisa mengungkapan idenya dalam bentuk tulisan,maka dari itu diperlukannya tindakan guru dalam membantu agar berani mengekspresikan idenya dalam bentuk tulisan. Maka, disusunlah penelitian ini untuk mengetahui apakah ada tindakantindakan guru dalam merespon keterampilan menulis siswa guna meningkatkan keterampilan menulisnya dengan judul "Kontribusi Tindak Pembelajaran Guru Kelas I SD Negeri 2 Dangin Puri Pada Peningkatan Keterampilan Menulis Siswa Tahun Ajaran 2019/2020"

\section{METODE PENELITIAN}

Penelitian ini dilaksanakan di SD Negeri 2 Dangin Puri. Penelitian ini berjenis kualitatif deskriptif dengan desain penelitian ini berbentuk etnografis. Subjek penelitian ini adalah Ibu Mega (bukan nama sebenarnya) dan siswa kelas 1 berjumlah 27 orang, terdiri dari 13 orang laki-laki dan 14 orang perempuan. Pengumpulan data pada penelitian ini menggunakan observasi dan wawancara.

Analisis data dalam penelitian ini dilakukan secara induktif analisis dilakukan untuk menentukan simpulan akhir terhadap data yang diperoleh dikumpulkan sedikit demi sedikit dari lokasi penelitian. Analisis data ini diadaptasi dari model interaktif yang dikembangkan oleh teori Miles dan Huberman (1984). Yang terbagi pada tahapan. Proses analisis data kualitatif berlangsung dalam tahapan, yaitu : 1) pengumpulan data, (2) reduksi data (data reducation), 3) paparan data (data display) dan 4) penarikan simpulan dan verifikasi (conclusion and verification).

Dalam penelitian ini triangulasi data bisa dilakukan melalui 3 cara yaitu dengan triangulasi (a) metode, (b) diskusi dengan pakar atau pembimbing, dan (c) tambahan waktu. Metode, dilakukan dari beberapa teknik pengumpulan data, yakni hasil catatan lapangan yang diperoleh di kelas dibandingan dengan hasil rekaman, hasil pengamatan dibandingkan hasil wawancara. Diskusi dengan pakar atau pembimbing, dilakukan dalam penelitian ini dengan cara mendiskusikan data yang telah terkumpul dengan pihak-pihak yang memiliki pengetahuan dan keahlian sesuai dengan penelitian ini. 


\section{ANALISIS DAN PEMBAHASAN}

Pada penelitian ini yaitu mengungkap bentuk - bentuk tindak pembelajaran guru pada saat mengajar mata pelajaran PPKn, Bahasa Indonesia dan Matematika (tematik) yang berkontribusi pada peningkatan keterampilan menulis siswa. Untuk mempermudah pemberian tindak pembelajaran guru, hasil dan temuan ini dipilah-pilah menurut fokus masalah penelitian ini, yakni (1) Tindak - tindak pembelajaran seperti apakah yang dilakukan guru kelas 1 SD pada setiap pembelajaran Bahasa Indonesia, Matematika dan PPKn, yang berkontribusi pada peningkatan keterampilan menulis siswa.

Tabel 1. Temuan Tindak Pembelajaran Guru yang Berkontribusi pada Peningkatan Keterampilan Menulis Pada Pembelajaran PPKn

\begin{tabular}{|c|c|c|c|c|c|c|c|}
\hline \multirow[b]{2}{*}{ No } & \multirow{2}{*}{$\begin{array}{c}\text { Kategori } \\
\text { Tindak } \\
\text { Pembelajar } \\
\text { an } \\
\end{array}$} & \multicolumn{2}{|c|}{ PPKn } & \multicolumn{2}{|c|}{ Bahasa Indonesia } & \multicolumn{2}{|c|}{ Matematika } \\
\hline & & $\begin{array}{c}\text { Tindak } \\
\text { Pembelajaran } \\
\text { Guru }\end{array}$ & Ulasan & $\begin{array}{c}\text { Tindak } \\
\text { Pembelajaran } \\
\text { Guru }\end{array}$ & Ulasan & $\begin{array}{c}\text { Tindak } \\
\text { Pembelajaran } \\
\text { Guru }\end{array}$ & Ulasan \\
\hline 1. & $\begin{array}{c}\text { Teacher. } \\
\text { Srtucturing }\end{array}$ & $\begin{array}{l}\text { Mempersilah- } \\
\text { kan } \\
\text { menyiapkan } \\
\text { buku latihan } \\
\text { dan catatan } \\
\text { serta } \\
\text { memperhati- } \\
\text { kan penjelasan } \\
\text { guru. }\end{array}$ & $\begin{array}{l}\text { Pada saat } \\
\text { itu guru } \\
\text { memberik } \\
\text { sn contoh } \\
\text { gambar } \\
\text { beberapa } \\
\text { kegiatan } \\
\text { yang } \\
\text { dapat } \\
\text { dilakukan } \\
\text { siswa baik } \\
\text { di rumah, } \\
\text { di sekolah, } \\
\text { maupun di } \\
\text { masyarak } \\
\text { at. }\end{array}$ & $\begin{array}{l}\text { Mengingatka } \\
\mathrm{n} \text { siswa } \\
\text { tentang } \\
\text { teknik } \\
\text { meyalin yang } \\
\text { benar. } \\
\text { Meminta } \\
\text { siswa untuk } \\
\text { menyiapkan } \\
\text { buku } \\
\text { latihannya. }\end{array}$ & $\begin{array}{l}\text { Disampai } \\
\text {-kan } \\
\text { kepada } \\
\text { siswa } \\
\text { dengan } \\
\text { mimik } \\
\text { wajah } \\
\text { serius, } \\
\text { nada } \\
\text { suara } \\
\text { tinggi, } \\
\text { dan } \\
\text { berulang- } \\
\text { ulang. }\end{array}$ & $\begin{array}{l}\text { Mempersi- } \\
\text { lahkan siswa } \\
\text { untuk } \\
\text { membuka } \\
\text { buku dan } \\
\text { mengingatkan } \\
\text { siswa tentang } \\
\text { materi } \\
\text { mengukur } \\
\text { dan } \\
\text { membandi- } \\
\text { ngkan berat } \\
\text { badan dengan } \\
\text { alat ukur. }\end{array}$ & $\begin{array}{l}\text { Guru } \\
\text { mengin } \\
\text { gat-kan } \\
\text { siswa } \\
\text { tentang } \\
\text { materi } \\
\text { menguk } \\
\text { ur dan } \\
\text { memba } \\
\text { ndi- } \\
\text { ngkan } \\
\text { berat } \\
\text { badan } \\
\text { dengan } \\
\text { alat } \\
\text { ukur }\end{array}$ \\
\hline 2. & $\begin{array}{c}\text { Teacher } \\
\text { Soliciting }\end{array}$ & $\begin{array}{l}\text { Memberikan } \\
\text { gambar kepada } \\
\text { siswa untuk } \\
\text { membaca dan } \\
\text { menulis } \\
\text { beberapa } \\
\text { pengalaman } \\
\text { kegiatan yang } \\
\text { pernah } \\
\text { dilakukan atau } \\
\text { dilihatnya } \\
\text { dalam } \\
\text { kehidupan } \\
\text { sehari-hari. }\end{array}$ & $\begin{array}{l}\text { Sambil } \\
\text { menunggu } \\
\text { siswa } \\
\text { mengerjak } \\
\text { an tugas } \\
\text { guru } \\
\text { berkeliling } \\
\text { dan } \\
\text { berjalan } \\
\text { mendekati } \\
\text { ke arah } \\
\text { beberapa } \\
\text { siswa } \\
\text { sambil } \\
\text { memperli } \\
\text { hat-kan } \\
\text { dan } \\
\text { kadang } \\
\text { mengorek } \\
\text { si jawaban } \\
\text { siswa. }\end{array}$ & $\begin{array}{l}\text { Memberikan } \\
\text { tugas pada } \\
\text { siswa } \\
\text { membuat } \\
\text { kalimat } \\
\text { pemberitahu } \\
\text { an melalui } \\
\text { gambar yang } \\
\text { disediakan } \\
\text { guru. } \\
\text { Memberikan } \\
\text { tugas pada } \\
\text { siswa untuk } \\
\text { menyusun } \\
\text { kalimat } \\
\text { pemberitahu } \\
\text { an sesuai } \\
\text { dengan } \\
\text { contoh yang } \\
\text { telah } \\
\text { dijelaskan } \\
\text { guru }\end{array}$ & $\begin{array}{l}\text { Tidak } \\
\text { ditemuka } \\
\mathrm{n} \text { tindak } \\
\text { pembelaj } \\
\text { a-ran } \\
\text { guru } \\
\text { yang } \\
\text { diorienta } \\
\text { si-kan } \\
\text { pada } \\
\text { latihan } \\
\text { menulis } \\
\text { untuk } \\
\text { menyam- } \\
\text { paikan } \\
\text { informasi } \\
\text { mencerit } \\
\text { a-kan } \\
\text { secara } \\
\text { singkat } \\
\text { isi } \\
\text { bacaan } \\
\text { yang } \\
\text { telah } \\
\text { disalinny }\end{array}$ & $\begin{array}{l}\text { Menugas-kan } \\
\text { siswa untuk } \\
\text { mengukur } \\
\text { berat benda } \\
\text { kemudian } \\
\text { menuliskan } \\
\text { hasil ukur di } \\
\text { buku tulis. }\end{array}$ & $\begin{array}{l}\text { Guru } \\
\text { menuga } \\
\text { s-kan } \\
\text { siswa } \\
\text { untuk } \\
\text { menguk } \\
\text { ur berat } \\
\text { benda } \\
\text { kemudi } \\
\text { an } \\
\text { menulis } \\
\text { kan } \\
\text { hasil } \\
\text { ukur di } \\
\text { buku } \\
\text { tulis. }\end{array}$ \\
\hline
\end{tabular}




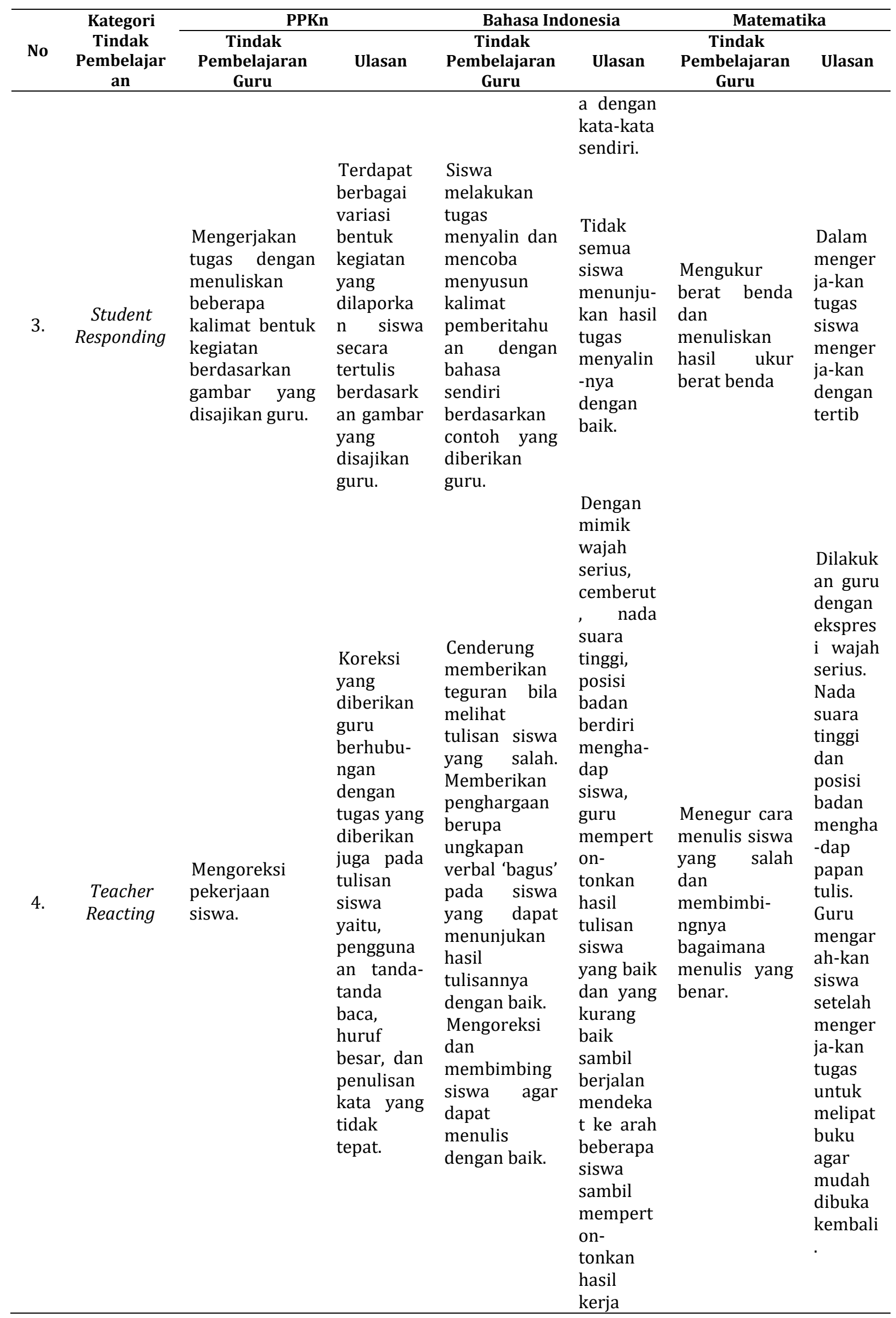




\begin{tabular}{|c|c|c|c|c|c|c|c|}
\hline \multirow[b]{2}{*}{ No } & \multirow{2}{*}{$\begin{array}{c}\text { Kategori } \\
\text { Tindak } \\
\text { Pembelajar } \\
\text { an }\end{array}$} & \multicolumn{2}{|c|}{ PPKn } & \multicolumn{2}{|c|}{ Bahasa Indonesia } & \multicolumn{2}{|c|}{ Matematika } \\
\hline & & $\begin{array}{c}\text { Tindak } \\
\text { Pembelajaran } \\
\text { Guru } \\
\end{array}$ & Ulasan & $\begin{array}{c}\text { Tindak } \\
\text { Pembelajaran } \\
\text { Guru }\end{array}$ & Ulasan & $\begin{array}{c}\text { Tindak } \\
\text { Pembelajaran } \\
\text { Guru } \\
\end{array}$ & Ulasan \\
\hline & & & & & $\begin{array}{l}\text { siswa } \\
\text { yang baik } \\
\text { dan yang } \\
\text { kurang } \\
\text { baik. }\end{array}$ & & \\
\hline
\end{tabular}

Terdapat implikasi temuan yang didapatkan setelah memberikan tindak pembelajaran guru yang berkontribusi pada peningkatan keterampilan menulis siswa kelas 1. Dikarenakan dapat meningkatkan kemampuan siswa yang dibuktikan pada hasil observasi dan wawancara yang telah dilaksanakan. Temuan implikasi secara praktis hasil dari penelitian yang dilakukan dapa memberikan acuan bagi guru agar lebih meningkatkan tindak yang dilakukan dengan penggunaan metode observasi dan wawancara secara efektif dan seusai dengan kegiatan yang dilaksanakan agar tercapainya tujuan pembelajaran agar pembelajaran menjadi menyenangkan dan bermakna bagi siswa. Adanya penambahan waktu observasi dan wawancara agar memperakuratkan hasil penelitian dapat meningkatkan keterampilan siswa dan kecerdasan siswa. Pemasalahan yang sering terjadi pada anak sekolah dasar terdapat siswa yang belum mampu memahami teknik menulis yang benar, siswa belum mampu menyusun kalimat menggunakan kosa kata yang tepat, siswa cenderung sulit mengungkapkan ide atau gagasan dalam bentuk tulisan, tidak semua siswa percaya diri dalam menunjukkan hasil tulisan. Menerapkan 4 tindak dalam pembelajaran agar mampu mengembangkan siswa dalam pembelajaran yang lebih maju dan membuat siswa semakin aktif dalam pembelajaran khususnya dikelas rendah peran guru sangatlah di perlukan dalam membimbing dan memotivasi siswa dalam keterampilan menulis.

Penelitian ini mendukung hasil penelitian sebelumnya yang disampaikan oleh Penelitian oleh Yanti dkk (2013), menyatakan perbedaan signifikan keterampilan menulis karangan narasi dalam mata pelajaran Bahasa Indonesia antara kelompok siswa yang mengikuti pembelajaran model Moody dengan memanfaatkan cerita rakyat siswa dibelajarkan pembelajaran konvensional pada siswa kelas IV SDN 1 Ubud. Penelitian oleh Evayanti, dkk (2016), menyatakan bahwa peningkatan keterampilan menulis siswa yang diterapkan metode Mind Mapping kelas IIIA SDN 1 Sumerta yang dibuktikan dengan adanya peningkatan nilai yang dapat dilihat dari persentase rata-rata nilai keterampilan menulis surat pribadi siswa. Penelitian yang dilakukan oleh Moh. Irtadji (2014) menunjukkan bahwa banyak tindak pembelajaran yang dilakukan oleh guru agar bisa menumbuhkembangkan kreativitas siswa adalah menciptakan lingkungan psikologis yang aman dan menggunakan berbagai macam metode pembelajaran. Tindak pembelajaran tersebut diantaranya yaitu Teacher Structuring, Teacher Soliciting, Teacher Reacting dan Student Responding.

\section{KESIMPULAN}

Berdasarkan hasil penelitian, menunjukkan bahwa tindak pembelajaran guru kelas 1 sekolah dasar terteliti yang berkontribusi pada peningkatan keterampilan menulis siswa pada pembelajaran tematik secara kuantitas maupun variasinya relative sedikit tindak verbal maupun nonverbal. Adapun tindaktindak pembelajaran guru yang tercetus dalam bentuk pengajuan pertanyaan, bimbingan, teguran, pemberian tugas, reward atau pemberian motivasi, baik verbal maupun nonverbal dilakukan tanpa rencana. Kontribusi tindak pembelajaran guru pada peningkatan keterampilan menulis siswa, guru menekankan pada pemberian tugas mebuat kalimat kemudian mengoreksi pekerjaan siswa dalam teknik menulis yang benar. Selain itu, guru juga mengembangkan imajinasi siswa dengan menunjukkan gambargambar. Dalam meningkatkan keterampilan menulis, penting bagi siswa belajar menuangkan gagasan, mengkomunikasikan pikirannya secara tertulis dengan tepat walau dalam wujud yang sederhana. Salah satu tujuan menulis adalah memberikan pengalaman beragam tulisan. Dengan demikian, siswa akan mempunyai bekal untuk berbagai tujuan menulis. Tindak pembelajaran verbal guru yang berkontribusi pada peningkatan keterampilan menulis yaitu guru memperlihatkan gambar kepada siswa yang berkaitan dengan kerja sama (T. Sructuring) kemudian menugaskan siswa untuk membuat sebuah kalimat sesuai gambar yang disajikan oleh guru pada buku tulis (T. Soliciting). Guru memberikan bimbingan agar siswa mampu mengerjakan tugas dengan benar ( $T$. Reacting). Tindak nonverbal berupa sikap badan yang mendekat kearah siswa, suara yang jelas dan mimik muka. Hasil penelitian ini dengan dengan implikasi temuan menunjukkan tindak pembelajaran guru kelas 1 yang berkontribusi dalam peningkatan 
keterampilan menulis siswa pada pembelajaran tematik secara kuantitas maupun variasinya relative sedikit tindak verbal maupun nonverbal.

\section{DAFTAR PUSTAKA}

Arista, N. L. P. Y., \& Putra, D. K. N. S. (2019). Pengaruh Model Pembelajaran Think Talk Write ( TTW ) Berbasis Literasi terhadap Keterampilan Menulis dalam Bahasa Indonesia. International Journal of Elementary Education, 284-292. https://doi.org/http://dx.doi.org/10.23887/ijee.v3i3.19413

Dalman. (2014). Keterampilan Menulis. Jakarta:Rajawali Pers.

Desimyari, M., \& Manuaba, I. B. S. (2019). Pengaruh Model Think Talk Write Berbantuan Media Audio Visual Terhadap Keterampilan Menulis Siswa. Jurnal Pedagogi Dan Pembelajaran, 2(1), 141. https://doi.org/10.23887/jp2.v2i1.17621

Dwitha Evayanti, A. M., \& Sumantri, M. (2017). Penerapan Metode Mind Mapping Untuk Meningkatkan Keterampilan Menulis Surat Pribadi Siswa Kelas IIIA. Jurnal Ilmiah Sekolah Dasar, 1(1), 42. https://doi.org/10.23887/jisd.v1i1.10124

Irtadji, M. (2014). Tindak Pembelajaran Guru yang Menumbuhkembangkan Kreativitas Siswa. Jurnal Pendidikan Humaniora, 2(1), 1-10. https://doi.org/10.17977/jph.v2i1.4438

Isna Ilvi Nurrohmah, Suharmono Kasiyun, Nafi ' ah, M. T. (2020). Pengaruh Media Pop Up Book Terhadap Keterampilan Bahasa Indonesia SD. SEJ (School Education Journal), 10(1).

Mesterianti, M., Simarmata, M. Y., \& Firtawati, S. (2019). Penerapan Model Think Talk Write Untuk Meningkatkan Keterampilan Menulis Bagi Siswa Sekolah Menengah Pertama. Edukasi: Jurnal Pendidikan, 17(1), 98. https://doi.org/10.31571/edukasi.v17i1.1083

Miles \& Huberman. (1992). Analisis Data Kualitatif. Jakarta:Universitas Indonesia.

Tarigan, H. G. (2008). Menulis Sebagai Suatu Keterampilan Berbahasa. Jakarta:Angkasa.

Yanti, D. A. S., Agung, A. A. G., \& Suwatra, I. I. W. (2013). Keterampilan Menulis Karangan Narasi Pada Siswa Kelas IV SDN 1 Ubud.

Yogyantoro, A. (2016). Peningkatan Keterampilan Menulis Karangan Deskripsi Menggunakan Media Diorama Siswa Kelas Iv Essays Description Writing Skills Improvement Using Media Diorama At Class Iv. Jurnal Pendidikan Guru Sekolah Dasar, 3(571), 1-10. http://journal.student.uny.ac.id/ojs/index.php/pgsd/article/viewFile/5378/5085 